\title{
PENGGUNAAN PROSES GURU (GROUND, UNDERSTAND, REVICE, USE) UNTUK MENINGKATKAN EFIKASI DIRI KARIER MAHASISWA CALON GURU BK
}

\author{
Khususiyah ${ }^{1}$, Nora Yuniar Setyaputri², Galang Surya Gumilang², Rosalia Dewi Nawantara ${ }^{4}$ \\ Universitas Nusantara PGRI Kediri 1,2,3,4 \\ khususiyah@unpkediri.ac.id' \\ rosaliadewi11@gmail.com ${ }^{4}$
}

\begin{abstract}
ABSTRAK
Penelitian ini dilatarbelakangi oleh hasil pengamatan peneliti dimana terdapat kurangnya efikasi diri karier mahasiswa S1 Bimbingan dan Konseling tahun ajaran 2018/2019 Prodi BK Universitas Nusantara PGRI Kediri. Hal ini ditandai dengan adanya kebimbangan mereka akan studi lanjut ataukah bekerja, apakah mereka dapat menjadi konselor yang profesional, mampukah mereka nanti menyesuaikan diri dengan iklim sekolah, keinginan diri yang tidak sesuai dengan kehendak orang tua, serta tersedianya lapangan pekerjaan bagi mereka atau tidak nantinya. Rendahnya efikasi diri karier ini dapat ditingkatkan dengan menggunakan Proses GURU. Proses GURU merupakan suatu teknik yang luwes dan komplit serta dinilai mampu mengakomodasi dari banyaknya tahapan pembelajaran ekperiensial. GURU merupakan kepanjangan dari ground $(G)$, understand $(U)$, revise $(R)$ dan use $(U)$. Tujuan penelitian ini adalah mengetahui tingkat efikasi diri karier mahasiswa Calon Guru BK sebelum dan sesudah diintervensi menggunakan Proses GURU. Pendekatan penelitian yang digunakan adalah kuantitatif dengan teknik penelitian experiment dengan jenis one group pretest posttest design. Skala Pengukuran Efikasi Diri Karier adalah instrumen yang digunakan dalam penelitian ini. Berdasarkan hasil penelitian diperoleh data dari perhitungan uji t paired sample bahwa sigifikansi yang diperoleh dari perbedaan skor posttest dan pretest adalah 0,000 dimana skor signifikansi ini kurang dari 0,05 . Maka $\mathrm{H}_{0}$ ditolak atau efikasi diri karier mahasiswa calon Guru BK meningkat setelah diberi perlakuan. Oleh karena itu, Guru BK/konselor dan para dosen BK dapat menggunakan Proses GURU untuk meningkatkan efikasi diri karier mahasiswa calon Guru BK. Selain itu Guru BK dan para dosen BK dapat menggunakan proses GURU ini sebagai teknik untuk pengembangan pribadi konselor.
\end{abstract}

Cara mengutip: Khususiyah, Setyaputri, N.Y., Gumilang, G.S. \& Nawantara, R.D. (2019) Penggunaan Proses GURU (Ground, Understand, Revise, Use) untuk Meningkatkan Efikasi Diri Karier Mahasiswa Calon Guru BK. Jurnal Nusantara of Research, 6(1) 16-25.

\section{PENDAHULUAN}

Dewasa ini banyak dijumpai bahwa konseli kerap tidak yakin untuk memutuskan akan kemana mereka nantinya. Ketidakyakinan konseli tersebut antara lain berhubungan dengan jenis pekerjaan yang hendak ditekuni dan pemilihan studi lanjut. Banyak faktor yang membuat mereka tidak yakin antara lain tidak adanya dukungan dari orang tua dan teman sebayanya, faktor ekonomi yang tidak mendukung atau mereka sebenarnya belum memahami potensi diri mereka sendiri dan cenderung pasrah dengan keadaan. Dapat diketahui bahwa permasalahan ini tidak hanya terjadi pada siswa atau pelajar yang sedang duduk di bangku sekolah menengah 
saja. Permasalahan ini tetap ada bahkan dapat berlanjut sampai pelajar tersebut duduk pada bangku kuliah atau mahasiswa. Akan menjadi sebuah problematik tersendiri apabila yang memiliki keyakinan diri yang rendah terhadap keberlasungan kariernya ini merupakan mahasiswa jurusan S1 Bimbingan dan Konseling. Hal ini dikhawatirkan akan mempengaruhi bagaimana kompetensi mereka nantinya apabila telah menjadi Guru BK.

Menurut Bandura (1993; 1994; 2006; 2009) efikasi diri merupakan keyakinan seseorang mengenai kemampuan yang dimiliki untuk melakukan suatu kinerja guna mencapai apa yang diinginkan. Ahli Teori Belajar Sosial tersebut juga menambahkan efikasi diri mempunyai pengaruh yang signifikan terhadap pengambilan keputusan karier individu (Bandura dkk, 2001; Betz, 2007; Bozgeyikli dkk, 2009; Hackett dalam Bandura, 2009). Efikasi diri yang berkaitan dengan pengambilan keputusan karier dapat disebut sebagai efikasi diri karier. Efikasi diri karier adalah keyakinan individu pada kemampuan dirinya untuk melakukan aksi terkait dengan aktivitasnya hingga mendapatkan sebuah keberhasilan kariernya ke depan (Feehan \& Johnston (1999); Anderson \& Betz (2001) dan Lenz \& Hackett (1987) dalam Brusokas \& Malinauskas (2014). Dapat ditarik kesimpulan efikasi diri karier adalah keyakinan dalam diri individu akan kemampuannya dalam melakukan aktivitas guna mendukung keberhasilan atau cita-citanya di masa depan.

Berdasarkan hasil studi pendahuluan dengan menggunakan wawancara terbuka kepada mahasiswa semester 6 Prodi S1 BK Universitas Nusantara PGRI Kediri tahun ajaran 2018/2019, ditemukan gejala-gejala rendahnya efikasi diri karier mereka. Fenomena ini berawal ketika peneliti mengajukan pertanyaan secara klasikal pada mahasiswa semester 6 mengenai apakah nantinya setelah lulus S1 BK para mahasiswa ini telah mantap menjadi konselor. Perbandingan antara mahasiswa yang mantab menjadi Guru BK dengan yang tidak mantap berkisar antara 1:3. Kurangnya efikasi diri karier yang terjadi pada mahasiswa calon Guru BK ini ditandai dengan adanya kebimbangan mereka akan studi lanjut ataukah bekerja, apakah mereka dapat menjadi konselor yang profesional, mampukah mereka nanti menyesuaikan diri dengan iklim sekolah, keinginan diri yang tidak sesuai dengan kehendak orang tua, serta tersedianya lapangan pekerjaan bagi mereka atau tidak nantinya.

Efikasi diri karier berawal dari sisi kognitif individu dan merupakan hasil belajar seseorang. Proses GURU adalah teknik yang dipilih untuk meningkatkan efikasi diri karier tersebut karena merupakan bagian dari model praktik reflektif (Schon, 1983) yang juga mengandalkan aktifitas kognitif. Praktik reflektif ini adalah bagian dari metode experiential learning atau metode belajar dari pengalaman (Silberman, 2007). Berakar dari praktik reflektif dan belajar eksperiensial, proses GURU dikembangkan oleh Brian Remer dan merupakan suatu teknik yang luwes dan komplit serta dinilai mampu mengakomodasi dari banyaknya tahapan bembelajaran ekperiensial (Remer, 2007).

GURU adalah kepanjangan dari ground $(G)$, understand $(U)$, revise $(R)$ dan use $(U)$. Penjelasan dari tahapan GURU yang telah disarikan dari penejelasan Remer (2007) adalah sebagai berikut. Ground merupakan tahap dalam mengungkap pemahaman dasar seseorang. Understand membantu individu untuk memahami diri dan juga memahami pilihan kariernya yang nantinya dapat digunakan untuk mengembangkan keterampilan analisisnya. Revise 
memungkinkan individu mengarahkan kecakapan kognitifnya untuk melakukan proses sintesis dan wicara diri agar senantiasa terjadi penilaian dan refleksi. Sedangkan Use memungkinkan individu untuk melakukan kegiatan penilaian dan eksekusi terhadap hasil revisi dari tahap sebelumnya sehingga dapat mengambil komitmen berupa perencanaan tindakan secara operasional dan sistematis.

Menurut Remer dalam Silberman (2007) proses GURU bisa diterapkan dalam berbagai situasi belajar dan pelatihan untuk meningkatkan suatu keterampilan tertentu. Hal ini tidak menutup kemungkinan dapat digunakan untuk meningkatkan efikasi diri karier pada calon konselor. Pada praktiknya proses GURU tetap menitikberatkan pada pengalaman individu. Pengalaman erat hubungannya dengan faktor kognitif individu. Jika dikaitkan dengan Teori Belajar Sosial, sumber yang paling berpengaruh dari efikasi diri adalah pengalaman belajar (mastery experience) (Bandura, 1977). Hal ini berkaitan dengan bagaimana calon konselor mengelola, menanggapi dan mempersepsikan pengalaman yang telah mereka alami sehingga berpengaruh pada tingkat efikasi diri karier mereka.

Terkait dengan pemaparan di atas maka hal tersebut perlu dikritisi oleh pengajar para calon konselor. Jika mereka yang nantinya diharapkan dapat membimbing siswanya ternyata masih mempunyai efikasi diri karier yang rendah terhadap profesinya, dikhawatirkan hal ini akan berpengaruh pada kinerja mereka di sekolah maupun di luar sekolah. Perlu dilakukan upaya tersendiri untuk menyelesaikan permasalahan ini dan sebagai sarana dalam peningkatan efikasi diri karier calon konselor. Selain itu, upaya ini dapat digunakan untuk mendukung tugas konselor di jenjang perguruan tinggi. Santoso (2011) menyatakan bahwa di jenjang perguruan tinggi pelayanan bimbingan dan konseling lebih difokuskan pada pemantapan karier, sebisa mungkin yang paling cocok baik dengan rekam jejak pendidikannya maupun kebutuhan untuk mengaktualisasikan dirinya sebagai pribadi yang produktif, sejahtera serta berguna untuk manusia lain. Pemberian informasi mengenai efikasi diri karier akan lebih terbantu dengan adanya media. Maka perlu dilakukan sebuah penelitian tentang peningkatan efikasi diri karier mahasiswa S1 BK dengan menggunakan teknik seperti Proses GURU tersebut.

Adapun kaitan proses GURU tersebut dengan bidang karier telah dibuktikan oleh penelitian Hanggara (2016) yang berjudul Keefektifan "Proses GURU" sebagai Teknik Bimbingan Kelompok dalam Meningkatkan Kemampuan Pengambilan Keputusan Karier Siswa SMK. Hasil penelitian ini membuktikan bahwa kemampuan pengambilan keputusan karier siswa SMK dapat ditingkatkan setelah dilakukan intervensi dengan menggunakan proses GURU. Maka dengan hasil penelitian tersebut memperkuat bahwa proses GURU dapat digunakan untuk meningkatkan efikasi diri karier mahasiswa calon Guru BK.

\section{METODE}

Metode penelitian yang digunakan dalam penelitian ini adalah experiment. Experiment adalah teknik penelitian yang menguji apakah variabel independent dapat mempengaruhi variabel dependent (Cresswell, 2012). Menurut Cohen (2007), penelitian experiment adalah penelitian yang didalamnya terdapat suatu intervensi dan pengukuran sebelum dan setelah diberikan intervensi. Adapun pada penelitian ini yang menjadi variabel 
independent adalah proses GURU dan variabel dependent adalah efikasi diri karier mahasiswa calon Guru BK. Teknik ini digunakan karena untuk mengetahui adakah peningkatan efikasi diri mahasiswa S1 BK sebelum dan sesudah diberikan paket pelatihan menggunakan proses GURU. Secara khusus jenis experiment yang digunakan dalam penelitian ini adalah pre experiment dengan one group pretest posttest design. Pre experiment belum merupakan eksperimen sungguh-sungguh karena terdapat variabel lain yang ikut berpengaruh terhadap terbentuknya variabel dependent (Sugiyono, 2012).

Penelitian ini dilaksanakan di Program Studi Bimbingan dan Konseling Universitas Nusantara PGRI Kediri selama tiga bulan, yakni antara bulan Februari sampai Mei 2017. Mahasiswa semester 6 Prodi Bimbingan dan Konseling UN PGRI Kediri tahun ajaran 20182019. Subjek penelitian dipilih dengan menggunakan teknik purposive sampling. Teknik ini dipilih dengan kriteria: 1) mahasiswa semester 6 S1 BK UN PGRI Kediri tahun ajaran 20182019 yang memiliki tingkat efikasi diri karier rendah dan sangat rendah; 2) mahasiswa tersebut telah melaksanakan MAGANG 2.

Skala Pengukuran Efikasi Diri Karier merupakan instrumen penelitian yang digunakan dalam penelitian ini. Adapun analisis hitung pelaksaam pre-posttest yang digunakan untuk menentukan tingkat efikasi diri karier mahasiswa adalah menggunakan rumus Sturgess yakni untuk menentukan 1) kelas ( $k$ ): $K=1+3,3 \log n ; 2)$ rentang ( $R$ ): $R=$ nilai maks-nilai min; 3 ) interval (i): $\mathrm{i}=\mathrm{K} / \mathrm{R}$. Untuk uji hipotesis dilakukan perhitungan menggunakan Paired Sample $T$-test dengan bantuan program SPSS IBM Statistic 20.0 apabila data terbukti normal dan homogen. Apabila data tidak normal dan tidak homogen maka perhitungan yang digunakan adalah Wilcoxon Sign Ranks Test. Pengujian ini menggunakan ketentuan sebagai berikut: 1) apabila signifikansi $>0,05$ maka $\mathrm{H}_{\mathrm{O}}$ diterima dan 2) apabila signifikansi $<0,05$ maka $\mathrm{H}_{\mathrm{O}}$ ditolak. Datadata yang bersifat non angka/verbal yakni berupa pendapat mahasiswa akan dideskripsikan dan digunakan sebagai bahan pendukung. Bahan pendukung untuk menarik kesimpulan dari deskripsi tersebut, sehingga memberikan gambaran yang jelas terhadap aspek yang dinilai.

\section{HASIL}

Penelitian ini dilaksanakan pada 10 mahasiswa S1 BK tingkat 3 UN PGRI Kediri. Dimana untuk rekapitulasi hasil pretest dan posttest kesepuluh subjek serta hasil uji hipotesis dapat dilihat pada tabel 1 berikut.

Tabel 1. Rekapitulasi Hasil Analisis Data

\begin{tabular}{cccccc}
\hline No. & Inisial Subjek & Skor Pretest & Kriteria & Skor Posttest & Kriteria \\
\hline 1. & CGB1 & 45 & Tinggi & 65 & Sangat Tinggi \\
\hline 2. & CGB2 & 34 & Rendah & 67 & Sangat Tinggi \\
\hline 3. & CGB3 & 35 & Rendah & 60 & Sangat Tinggi \\
\hline 4. & CGB4 & 32 & Rendah & 55 & Tinggi \\
\hline 5. & CGB5 & 47 & Tinggi & 62 & Sangat Tinggi \\
\hline 6. & CGB6 & 36 & Rendah & 56 & Tinggi \\
\hline 7. & CGB7 & 27 & Sangat Rendah & 65 & Sangat Tinggi \\
\hline 8. & CGB8 & 46 & Tinggi & 64 & Sangat Tinggi \\
\hline 9. & CGB9 & 41 & Rendah & 63 & Sangat Tinggi \\
\hline 10. & CGB10 & 36 & Rendah & 66 & Sangat Tinggi \\
\hline Uji Hipotesis & & Diperoleh singnifikansi sebesar 0,000 < 0,05 & \\
\hline \multicolumn{7}{r}{} & (perhitungan uji hipotesis menggunakan SPSS 20 for windows) &
\end{tabular}


Pada Tabel 1 dapat diketahui bahwa kesepuluh subjek penelitian berada pada rentang tinggi (2 subjek), rendah (6 subjek) dan sangat rendah (2 subjek). Untuk posttest dapat diketahui bahwa kesepuluh subjek penelitian berada pada rentang tingg (2 subjek) dan sangat tinggi (8 subjek). Secara umum dapat dapat disimpulkan bahwa kriteria subjek mengalami peningkatan setelah dilakukan intervensi yaitu tidak terdapat lagi subjek yang berada pada rentang rendah dan sangat rendah jika dilihat perbandingan antara kriteria pada skor pretest dan posttest.

Dari hasil perhitungan hipotesis diperoleh nilai signifikansi atau nilai probabilitas kurang dari 0,05 , yaitu $0,000<0,05$. Maka $\mathrm{H}_{0}$ ditolak atau efikasi diri karier calon konselor meningkat setelah diberi perlakuan yaitu kegiatan bimbingan kelompok menggunakan teknik Proses GURU.

\section{PEMBAHASAN}

Berdasarkan hasil penelitian ini diperoleh data dari perhitungan paired sample t test bahwa sigifikansi yang diperoleh dari perbedaan skor posttest dan pretest adalah 0,000 dimana skor signifikansi ini kurang dari 0,05. Dapat ditarik kesimpulan bahwa efikasi diri karier mahasoswa calon guru BK dapat ditingkatkan setelah dilakukan intervensi menggunakan teknik Proses GURU. Hasil penelitian ini mendukung pemaparan-pemaparan di paragraf sebelumnya yang bersifat teoretis dimana Proses GURU ini dapat digunakan untuk meningkatkan efikasi diri karier mahasiswa calon Guru BK. Selain itu hasil penelitian ini mendukung bahwa ketika komponen-komponen yang terdapat dalam sistem Bimbingan dan Konseling dipenuhi, maka akan menambah kualitas pelaksanaan layanan BK yang dilakukan. Meskipun dalam setiap pelaksanaan layanan tidak menutup kemungkinan tetap mengalami kendala-kendala tertentu.

Senada dengan pendapat Nursalin (2013) yang menyatakan bahwa komponenkomponen yang terdapat dalam sistem BK meliputi: masalah, tujuan, teknik, media dan evaluasi. Komponen-komponen tersebut seyogyanya dapat dipenuhi dengan baik supaya tujuan dalam pemberian layanan Bimbingan dan Konseling ini dapat tercapai. Sepertinya halnya masalah yang dijumpai berdasarkan studi pendahuluan adalah rendahnya efikasi diri karier mahasiswa calon Guru BK, tujuan layanan yang bisa dirumuskan dari masalah ini meningkatkan efikasi diri karier tersebut. Kemudian dipilihlah sebuah teknik yang sesuai kondisi lapangan yang mayoritas memerlukan teknik yang praktis dan mudah dipalikasikan yaitu Proses GURU. Media yang dipakai adalah buku panduan eksoerimen serta evaluasi yang digunakan adalah evaluasi hasil. Dimana data untuk evaluasi ini diperoleh dari skala pengukuran efikasi diri karier.

Menurut Feehan \& Johnston (1999), Anderson \& Betz (2001) dan Lenz \& Hackett (1987) dalam Brusokas \& Malinauskas (2014) pengertian dari fikasi diri karier adalah kemantapan atau keyakinan individu pada kemampuan dirinya untuk melakukan aksi terkait dengan aktivitasnya hingga mendapatkan sebuah keberhasilan dalam bidang karier. Efikasi diri karier ini sangat penting untuk dimiliki oleh seseorang karena mempunyai pengaruh terhadap keberhasilan karier seseorang. Adapun fungsi penting tersebut yaitu seseorang yang mempunyai efikasi diri karier yang tinggi akan berusaha lebih keras untuk berhasil dalam bidang 
kariernya, mereka akan berusaha lebih giat untuk meningkatkan prestasi kerjanya, serta jika mereka mengalami kegagalan mereka dengan cepat memulihkan kembali semangat pada diri mereka tersebut.

Faktor yang mempengaruhi tingkat efikasi diri karier seseorang antara lain yang pertama adalah pengalaman belajar/pengalaman menguasai sesuatu (experience of mastery) merupakan interpretasi individu terhadap keberhasilan yang dicapainya pada masa lalu. Interpretasi ini mempengaruhi seberapa tinggi tingkat efikasi diri mereka serta akan mempengaruhi kemampuan dirinya pada kegiatan selanjutnya. Faktor yang kedua adalah pengamatan terhadap orang lain (vicarious experience). Hal ini dapat didefinisikan sebagai proses modeling atau belajar dari orang lain. Pengamatan terhadap orang lain ini menentukan persepsi akan keberhasilan atau kegagalan yang akan dicapai nantinya.

Faktor yang ketiga adalah persuasi sosial (social persuasion) yaitu persuasi yang dilakukan oleh pihak-pihak yang menjadi panutan dan memiliki kemampuan untuk mewujudkan hal yang diinginkan oleh individu tersebut. Persuasi sosial yang diberikan kepada individu bahwa individu memiliki kemampuan untuk dapat berhasil dalam bidang kariernya ini dapat menyebabkan ia semakin termotivasi untuk berusaha lebih giat. Faktor yang terakhir adalah kondisi emosi individu tersebut, apakah positif atau negatif (positive and negative emotional state). Hal ini berkaitan dengan penilaian individu dalam menilai kemampuan, kekuatan dan kelemahan dirinya. Penilaian mereka terhadap diri mereka sendiri ini pastinya akan mempengaruhi keyakinan individu dalam menjalankan aksi mereka. Berdasarkan beberapa fungsi penting dan faktor-faktor yang mempengaruhi efikasi diri karier ini sebagai seorang konselor seharusnya memberikan pelayanan khusus kepada konselinya mengenai pemantapan dan peningkatan efikasi diri karier agar mereka dapat berhasil dalam bidang kariernya.

Komponen lain yang tidak kalah penting adalah teknik. Kondisi lapangan pada umumnya memerlukan teknik-teknik yang mudah diaplikasikan dan tahapannya tidak terlalu panjang. Oleh karena itu dipilihlah proses GURU sebagai teknik untuk pemberian layanan BK mengenai efikasi diri karier tersebut. Proses GURU (Ground, Understand, Revise dan Use) adalah salah bentuk praktik reflektif yang berhubungan erat dengan konsep experiential learning. Terdapat satu kesamaan antara praktik reflektif dan experiential learning yaitu dalam proses pelaksanaannya mengutamakan pengalaman apa yang telah dialami seseorang dan merefleksikan pengalaman tersebut untuk mendapatkan perilaku baru yang lebih efektif dan produktif.

Proses GURU mempunyai 4 tahap yang sesuai dengan akronim GURU tersebut. Tahap yang pertama adalah Ground (Dasar/Pondasi), dimana dalam tahap ini seseorang diberikan pertanyaan-pertanyaan mendasar berkaitan dengan pengalaman yang telah mereka alami. Pemberian pertanyaan reflektif ini dimaksudkan untuk membantu individu untuk memahami serta mendeskripsikan pengalaman yang pernah mereka alami pada waktu yang telah lalu. Pengalaman ini sifatnya internal sehingga untuk memanggilnya kembali dalam memori mereka perlu menggunakan pertanyaan-pertanyaan yang dapat menstimulus aspek kognitif dan emosionalnya. Hasilnya merupakan data dasar, yaitu informasi yang memuat 
tentang pemahaman, pengetahuan atau pengalaman seseorang tersebut terhadap suatu hal atau topik tertentu. Jika dikaitkan dengan efikasi diri karier maka pengalaman masa lalu yang akan dipanggil adalah pengalaman masa lalu yang berkaitan dengan tingkat efikasi diri karier yang telah mereka alami.

Tahap yang kedua adalah Understand (Pemahaman). Tahap ini bertujuan agar seseorang mendapatkan pemahaman yang lebih luas dan lebih mendalam, terkait topik yang dipelajari yaitu efikasi diri karier. Dalam tahap ini diberikan berbagai informasi yang relevan lalu seseorang tersebut didorong untuk menelaah dan mengurai informasi apa yang diterimanya. Pada tahap ini juga digunakan pertanyaan-pertanyaan yang mendorong individu untuk dapat mengidentifikasi persamaan dan perbedaan antara data dasar pada tahap sebelumnya dengan apa yang yang dipelajari saat ini, baik berupa peristiwa, pemikiran ataupun tindakan mereka. Pertanyaan-pertanyaan lebih lanjut juga diberikan sedemikian rupa untuk mengarahkan mereka agar dapat mengungkapkan apa yang mereka pelajari dan membuat pandangan umum serta membuat hipotesis.

Dengan pemahaman ini maka konseli akan membangun pengalaman dan pengetahuanya lebih lanjut dan membandingkannya dengan pengalaman sebelumnya yang memungkinkannya untuk memperbaiki apa yang kurang efektif baginya dalam rangka mencapai sesuatu yang dituju. Hasilnya adalah diperolehnya pemahaman baru yang lebih luas serta mendalam dibandingkan dengan pengalamannya yang terpaparkan dalam data dasar, khususnya yang berkaitan dengan pengalaman baik kognitif maupun emosional terhadap efikasi diri karier mereka.

Tahap yang ketiga adalah Revise (Revisi). Tahap revisi ini merupakan tahap yang memungkinkan seseorang untuk memperbaiki pikiran dan aspek emosionalnya menjadi lebih baik. Tujuan dari tahap ini yaitu mengarahkan seseorang agar secara kreatif dapat memperbaiki apa yang dirasa kurang efektif dalam rangka mencapai tujuan yang ingin dicapai. Tahap ini merupakan tahap yang penting karena kreativitas dan keaktifan seseorang diberdayakan dan dikembangkan melalui berbagai pertanyaan-pertanyaan stimulasi. Kegiatan ini dilakukan setelah individu memiliki pemahaman yang cukup luas tentang topik yang telah dikembangkan dalam tahap sebelumnya sehingga dimungkinkan untuk menganalisis kelebihan dan kekurangan dari apa yang dipikirkan dan dirasakannya untuk digantikan atau direvisi menjadi lebih efektif.

Kegiatan revisi ini dimulai dengan memberikan pertanyaan-pertanyaan yang mengarahkan individu untuk mengidentifikasi berbagai aspek baik dalam pikiran maupun emosionalnya yang dirasa kurang efektif. Setelah itu dilanjutkan dengan memberikan pertanyaan yang mengarahkannya memperbaiki atau merevisinya menjadi lebih efektif. Hasil dari tahap ini adalah pemahaman atau pengalaman kognitif dan emosional yang lebih baik dan efektif untuk diaplikasikan pada kehidupan selanjutnya dalam rangka meningkatkan efikasi diri karier mereka.

Tahap keempat adalah Use (Penggunaan). Use atau tahap penggunaan merupakan tahapan puncak dalam proses GURU. Tujuan dari tahap ini membantu seseorang 
merencanakan tindakan mereka berikutnya. Melalui tahap kegiatan ini konseli akan dapat mengambil suatu komitmen secara operasional, rinci dan lebih riil tentang tindakan apa saja yang hendak dilakukan dan bagaimana komitmen tersebut dilakukan guna mencapai tujuannya. Tahap ini dilakukan dengan cara memberikan pertanyaan-pertanyaan yang membantu orang berpikir mengenai apa yang mereka ingin lakukan dengan informasi baru dan ide-ide yang telah mereka pelajari serta pertanyaan tentang bagaimana mereka melakukanya. Selanjutnya mendorong mereka untuk mempertimbangkan bagaimana menggunakannya dalam berbagai kesempatan dan aspek kehidupan mereka. Hasil dari tahap ini adalah dirumuskanya rencana tindakan yang operasional, rinci dan lebih riil dimana memungkinkan individu untuk mengaplikasikanya dengan lebih mudah dan bertanggung jawab.

Dengan meggunakan proses GURU, seseorang dapat: a) mempertimbangkan dan menentukan tindakan apa yang akan dilakukan untuk merespon situasi yang sedang dialami; b) mengontrol tingkat emosi; c) mempercepat proses adaptasi dengan lingkungan baru; d) mengubah arah pikir konseli, yang semula mempunyai pola pikir yang kurang/tidak efektif menjadi pola pikir yang lebih efektif; e) lebih cermat dalam mempertimbangkan informasi; f) dapat mengevaluasi kinerja/tindakan yang telah dilakukan atau dapat menentukan keefektifan dari tindakan tersebut; dan g) dapat merencanakan tindakan apa saja yang perlu dilakukan untuk situasi selanjutnya (Remer, 2007). Remer (2007) juga mengungkapkan bahwa proses GURU ini bersifat luwes. Maksudnya dengan sifat luwes ini, proses GURU dapat diaplikasikan sebagai teknik dalam strategi apapun dan tahapan yang dimiliki pun tidak terlalu panjang. Pertanyaan-pertanyaan reflektif yang menjadi ciri utama proses GURU ini dapat diberikan dalam strategi BK dalam bentuk apapun misalnya seperti bimbingan kelompok.

Bimbingan kelompok memiliki peran yang sifatnya lebih pada pencegahan terjadinya suatu permasalahan dalam diri individu (DeLucia-Waack, 2006). Corey dkk (2014) menyatakan bahwa bimbingan kelompok fokus pada pengembangan kognitif, afektif dan keterampilan tingkah laku anggotanya melalui serangkaian prosedur terstruktur dalam pertemuan kelompok. Jadi, dengan menggunakan strategi layanan berupa bimbingan kelompok, pengubahan pola pikir individu dan pembentukan tingkah laku baru dapat dikembangkan. Pola pikir dan tingkah laku baru yang akan dikembangkan berkaitan dengan efikasi diri karier seseorang. Menurut DeLucia-Waack (2006) satu kelompok jumlah ideal anggotanya jika berusia lebih dari 9 tahun adalah 5-8 anggota. Durasi dalam satu sesi bimbingan juga telah disimpulkan jika usia masingmasing anggota dalam satu kelompok lebih dari 9 tahun adalah 40-70 menit (DeLucia-Waack, 2006).

Berdasarkan penjelasan di atas maka proses GURU dapat digunakan sebagi teknik bimbingan kelompok. Sedangkan posisi media BK berupa paket pelatihan adalah sebagai sarana/wadah materi yang akan diberikan dalam pelaksanaan bimbingan. Menurut pendapat Remer (2007) dapat disimpulkan bahwa dalam pelaksanaan proses GURU tersebut selain menggunakan pertanyaan reflektif dapat digunakan pula media-media tertentu disesuaikan dengan materi dan karakteristik individu yang akan dilatih. Individu yang akan dilatih dalam penelitian ini adalah mahasiswa S1 Bimbingan dan Konseling atau dapat disebut sebagai calon Guru BK. 
Penelitian Hanggara (2016) yang berjudul Keefektifan "Proses GURU" sebagai Teknik Bimbingan Kelompok dalam Meningkatkan Kemampuan Pengambilan Keputusan Karier Siswa SMK telah membuktikan bahwa dengan menggunakan proses GURU kemampuan pengambilan keputusan karier siswa SMK dapat ditingkatkan. Dapat disimpulkan bahwa kemampuan pengambilan keputusan karier ini erat hubungannya dengan efikasi diri karier karena keduanya adalah memakai faktor kognitif individu, maka dengan hasil penelitian tersebut memperkuat bahwa proses GURU dapat digunakan untuk meningkatkan efikasi diri karier calon Guru BK.

Mengacu pada hasil studi pendahuluan yang tertulis dalam latar belakang masalah, ternyata calon konselor tersebut masih mempunyai efikasi diri karier yang rendah menganai profesi yang akan mereka tekuni nantinya. Rendahnya efikasi diri karier yang terjadi pada calon konselor ini ditandai dengan adanya kebimbingan berkaitan dengan kejelasan profesi mereka, akan studi lanjut ataukah bekerja, apakah mereka dapat menjadi guru BK/konselor yang profesional, mampukah mereka nanti menyesuaikan diri dengan iklim sekolah, keinginan diri yang tidak sesuai dengan kehendak orang tua, serta ketersediaan lapangan pekerjaan bagi mereka. Hal ini nampak sangat ironis karena jurusan yang mereka ambil adalah S1 BK yang diharapkan nantinya mereka dapat menjadi konselor yang profesional di lapangan, ternyata masih kurang mantap dan yakin mengenai profesi yang akan mereka tekuni nanti. Jika kurangnya efikasi diri karier calon konselor ini tidak segera ditangani dikhawatirkan problematik bimbingan dan konseling yang terjadi di lapangan tidak kunjung tereduksi.

\section{KESIMPULAN DAN SARAN}

Berdasarkan hasil penelitian ini dapat membuktikan bahwa Proses GURU dapat meningkatkan efikasi diri karier mahasiswa calon Guru BK, dengan bukti skor signifikansi dalam uji hipotesis sebesar $0,000<0,05$. Hal ini dapat diartikan bahwa hipotesis nol ditolak dan hipotesis alternatif diterima. Efikasi diri karier ini penting untuk dimiliki dan ditingkatkan pada diri seseorang karena memiliki pengaruh penting untuk keberhasilan karier mereka. Berdasarkan penelitian ini maka teknik yang terbutki efektif adalah dengan menggunakan proses GURU, dimana menurut penelusuran kajian teoretik dan penelitik terdahulu menyatakan bahwa teknik ini bersifat luwes serta mudah diaplikasikan dengan strategi bimbingan yang dipilih seperti bimbingan kelompok.

Berdasarkan kegiatan penelitian ini maka saran yang dapat diberikan oleh peneliti antara lain adalah: 1) Guru BK/konselor dan para dosen BK dapat menggunakan proses GURU untuk meningkatkan efikasi diri karier calon konselor; 2) Guru BK/konselor dan para dosen BK dapat menggunakan proses GURU ini sebagai teknik untuk pengembangan pribadi konselor.

\section{DAFTAR RUJUKAN}

Bandura, A. 1977. Self-efficacy: Toward a Unifying Theory of Behavioral Change. Psychological Review, Vol 84 (2): 191-215.

Bandura, A. 1993.Perceived Self-Efficacy in Cognitive Development and Functioning.Educational Phychologist, Vol 28 (2): 117-148. 
Bandura, A. 1994. Self-Efficacy. Encyclopedia of Human Behavior, Vol 4: 71-81.

Bandura, A. 1998.Personal and Collective Efficacy in Human Adaptation and Change. Hove, UK: Psychology Press.

Bandura, A., Barbaranelli, C., Caprara, G.V., \& Pastorelli, C. 2001. Self-Efficacy Beliefs as Shapers of Children's Aspirations and Career Trajectories.Child Development, Vol 72 (1): 187-206.

Bandura, A. 2006. Self-Efficacy Beliefs of Adolescent.hlm 307-337, (Online), (http://www.uky.edu/ eushe2/BanduraPubs/BanduraGuide2006.pdf), diakses 19 Maret 2013.

Bandura, A. 2009. Self Efficacy in Changing Societies. New York: Cambridge University Press.

Betz, N.E. 2007. Career Self-Efficacy: Exemplary Recent Research and Emerging Directions. Journal of Career Assessment, Vol 15 (4): 403-422.

Bozgeyikli, H., Eroglu, S.E., \& Hamurcu, H. 2009. Career Decision Making Self-Efficacy, Career Maturity and Socioeconomic Status with Turkish Youth. Georgian Electronic Scientific Journal: Education Science and Psychology, No. 1 (14): 15-24.

Brusokas, A. \& Malinauskas, R. 2014. Career self-efficacy among Lithuanian adolescents in sports schools. Procedia - Social and Behavioral Sciences, No. 116: 212-216.

Corey, M.; Corey, G; dan. Corey, C. 2014. Groups: Process and practice. $9^{\text {th }}$ Ed. Belmont, CA: Brooks/Cole.

DeLucia-Waack, J.L. 2006. Leading Psychoeducational Groups. California: Sage Publications, Inc.

Feehan, P.F. \& Johnston, J.A. 1999.The Self-Directed Search and Career Self-Efficacy.Journal of Career Assessment, Vol 7 (2): 145-159.

Hanggara, G.S. 2016.Keefektifan "Proses Guru” Sebagai Teknik Bimbingan Kelompok Dalam Meningkatkan Pengambilan Keputusan Karier Siswa SMK. Jurnal Kajian Bimbingan dan Konseling.Vol. 1(4): 148-157.

Nursalim, M. 2013. Pengembangan Media Bimbingan dan Konseling. Jakarta: PT Indeks.

Remer, B. 2007. Reflective Practice: Learning from Real-World Experience. Dalam Silberman, M, (ed). The Handbook of Experiential Learning.San Fransisco: John Wiley \& Sons. Inc.

Santoso, D.B. 2011.Dasar-dasar Bimbingan dan Konseling. Malang: Fakultas IImu Pendidikan Universitas Negeri Malang.

Schon, D.A. 1983. The Reflective Practitioner: How Professionals Think in Action. USA: Basic Book.

Silberman, M. 2007. The Handbook of Experiential Learning.San Fransisco: John Wiley \& Sons. Inc. 